\title{
¿Un nuevo Derecho civil para los animales?: Elogio (no exento de enmiendas) a la nueva Proposición de Ley sobre el régimen jurídico de los animales, en España
}

\author{
Guillermo Cerdeira Bravo de Mansilla \\ Catedrático de Derecho Civil \\ Universidad de Sevilla
}

Recepción: Abril 2021

Aceptación: Abril 2021

Cita recomendada. CERDEIRA BRAVO DE MANSILLA, G., ¿Un nuevo Derecho civil para los animales?: Elogio (no exento de enmiendas) a la nueva Proposición de Ley sobre el régimen jurídico de los animales, en España, dA. Derecho Animal (Forum of Animal Law Studies) 12/2 (2021). - DOI https://doi.org/10.5565/rev/da.573

\section{Resumen}

Presentada por PSOE y -al principio- por UNIDAS PODEMOS una "nueva" Proposición de Ley que pretende una reforma en materia de animales, frente al voto contrario de VOX por entender que se equiparan a las personas, el autor del presente trabajo entiende que dicha reforma legislativa es una respuesta obligada -aunque tardía- a una exigencia comunitaria que impone en toda la Unión Europea la protección del bienestar de los animales en cuanto seres vivos dotados de sensibilidad, lo que, según la propuesta española, los convierte en bienes -aunque- singulares, diversos de las simples cosas y de las personas, tratándolos con humanidad, mas sin llegar a humanizarlos. Así mismo, conforme al espíritu de la reforma propuesta, el autor sugiere numerosas enmiendas a muy diversas normas: algunas de ellas corregibles, o mejorables, otras -puede que- sobrantes o innecesarias, y otras, sin embargo, ausentes, a pesar de su trascendencia práctica.

Palabras clave: personas, cosas y animales; proposición de ley y enmiendas.

Abstract - A new Private law for animals? Praise (but not without amendments) for the new legal proposal on the legal regime of animals in Spain

A "new" legal proposal seeking a reform in the area of animals has been presented by PSOE, and firstly by UNIDAS PODEMOS, in the face of a vote to the contrary by VOX for its equation of animals with people. The author of this work understands this legislative reform to be an obligatory, albeit late, response to the community demands for welfare protection for animals as living beings endowed with sensibility across the whole European Union which, according to the Spanish proposal, makes them unique goods, different than simple things and people, to be treated with humanity, without being humanised. In this way, and in the spirit of the reform, the author suggests numerous amendments to a variety of regulations: some amendable or improvable, others perhaps excessive or unnecessary, and others, however, absent, despite their practical significance.

Keywords: people, things and animals; legal proposal and amendments. 


\section{Sumario}

I. Una "nueva" Proposición de Ley de modificación del Código Civil, la Ley Hipotecaria y la Ley de Enjuiciamiento Civil, sobre el régimen jurídico de los animales.

II. La Proposición de ley como obligada respuesta a nuestro Derecho comunitario, y autonómico.

1. Adecuación de la Proposición de ley española al Tratado de Funcionamiento de la Unión Europea, y a la necesaria protección del bienestar del animal -como ser vivo sensibleconsagrada como nuevo principio general del Derecho.

2. Inspiración de la Proposición de Ley española en algunos Códigos europeos, aunque con olvido -que cabría subsanar- de nuestro Derecho autonómico.

III. Entre personas y cosas: la consideración de los animales en la Proposición de Ley como bienes aunque- singulares sometidos supletoriamente al régimen jurídico de bienes. Y la consecuente propuesta de enmiendas.

1. La posición prudente de la Proposición, exenta de radicalismos extremos.

2. El novedoso reconocimiento del maltrato animal por su titular y, por ello, el posible olvido de su calificación -y refrendo- como abuso de derecho en el art. 7.2 CC.

3. La "falsa salida" de los animales como inmuebles por destinación en el nuevo art. $334 \mathrm{CC}$ y la consiguiente exclusión de sus posibles embargo e hipoteca inmobiliaria (en los nuevos arts. 605.1 LEC y $111.1^{\circ} \mathrm{LH}$ ), aunque con -posible- olvido de la prenda sin desplazamiento posesorio (del art. 52.3 LHMyPSD).

4. La posible "salida en falso" de los animales como bienes muebles en el nuevo art. $346 \mathrm{CC}, \mathrm{y}$ su indudable repercusión -sobre todo- en Derecho de familia (en los arts. 96, 1320, 1321 CC, entre otros, -tal vez- olvidados en la Proposición de ley).

5. La aclaración -posiblemente- innecesaria -y hasta perturbadora- del nuevo art. $1346.1^{\circ} \mathrm{CC}$ y el olvido en aclarar si la tenencia y el cuidado del animal son carga del matrimonio y forman parte de la potestad y del trabajo domésticos (los olvidados arts. 1319, 1362 y 1438 CC).

IV. Y a modo de epílogo: ¿otros posibles olvidos que enmendar en la nueva Proposición de Ley sobre animales?

Bibliografía

\section{Una "nueva" Proposición de Ley de modificación del Código Civil, la Ley Hipotecaria y la Ley de Enjuiciamiento Civil, sobre el régimen jurídico de los animales.}

Por iniciativa de los Grupos parlamentarios de PSOE y -al principio- de UNIDAS PODEMOS, se ha presentado una nueva Proposición de reforma legislativa en materia de animales (publicada en el BOCG de 26 de marzo de $2021^{1}$ ), que afecta a normas, sobre todo de Derecho Civil, tan importantes como el Código Civil (CC, en adelante), la Ley de Enjuiciamiento Civil y la Ley Hipotecaria. Una propuesta de reforma que el día 20 de abril del mismo año fue aceptada por el Parlamento para su tramitación (aunque tres días más tarde el Grupo podemista retirase su firma de la iniciativa).

Aunque esperada desde hace tiempo, no resulta ser muy novedosa u original en su contenido; sí lo es, por supuesto, respecto al régimen actualmente vigente habido sobre animales en aquellas normas mencionadas (de hasta revolucionaria cabría tildar la reforma propuesta); sino porque no es la primera vez que tal proposición se ha llevado a cabo en los últimos tiempos: ya hubo una anterior Proposición presentada por iniciativa del PP (publicada en el BOCG de 7 de septiembre de $2020^{2}$ ), y tiempo antes hubo otra propuesta de reforma, auspiciada también por el PP en octubre de 2017, que, admitida a trámite y debatida, llegó incluso a ser consensuada por todos los grupos parlamentarios (iquién lo iba a decir!) ${ }^{3}$, aunque finalmente malograda,

\footnotetext{
${ }^{1}$ Que puede verse en https://www.congreso.es/public_oficiales/L14/CONG/BOCG/B/BOCG-14-B-157-1.PDF\#page=1

${ }^{2}$ Que puede verse en https://www.congreso.es/public_oficiales/L14/CONG/BOCG/B/BOCG-14-B-99-1.PDF\#page=1

${ }^{3}$ Para cuyo comentario, cabe remitirse, entre otros, a los trabajos de AlÁEz Corral, B., Algunas claves de la futura reforma del Estatuto Jurídico civil del animal en España, en dA. Derecho Animal (Forum of Animal Law Studies) 9/3 (2018) 48-55 (tomado texto completo de Dialnet); o de ARRIBAS ATIENZA, P., El nuevo tratamiento civil de los animales, en Diario La Ley, ${ }^{\circ} 9136$, Sección Tribuna, 9 de Febrero de 2018 (tomado de internet).
} 
caducada, por los conocidos avatares políticos que siguieron en el tiempo, plagado de gobiernos provisionales y de continuas Elecciones Generales anticipadas, lo que obligó a que aquella Propuesta, consensuada ya en marzo de 2019 (y así publicada el mismo día uno de dicho mes en el BOCG), quedara abortada cuando apenas un mes después se anticiparon las Elecciones generales (una de tantas) ${ }^{4}$, lo que para muchos supuso una desilusión y la petrificación de un régimen codificado, y cosificado del animal, a todas luces "residual y anacrónico" 5 .

Tras aquellos avatares políticos vendrían los pandémicos y los estados de alarma por todos conocidos que, sabido es también, paralizaron por mucho tiempo la vida social en general, incluida la parlamentaria en muchos sentidos (incluido, en lo que aquí importa, la referida a sus iniciativas legislativas).

Recobrada, no obstante, de forma paulatina la normalidad, también la parlamentaria, a iniciativa del Gobierno se ha retomado aquella propuesta de reforma legislativa en materia de animales, cuyo contenido, además, como el de la otra Proposición presentada no hace mucho por el PP, es muy similar (casi idéntica en su mayoría, aunque con algunos cambios), a aquella propuesta de reforma legislativa consensuada el 1 de marzo de 2019. Al margen de la valoración política que merezca tan grande coincidencia en su contenido ${ }^{6}$, que a mí no me corresponde hacer como jurista, jurídicamente parece ello acertado a fin de lograr lo más pronto posible un acuerdo, un consenso lo más generalizado posible en su aprobación definitiva; lo cual, sin embargo, no parece que sea fácil: en su admisión a trámite aprobada por el Parlamento el 20 de abril, la gran mayoría parlamentaria se mostró a favor (con 295 votos y ninguna abstención), aunque con 52 votos en contra, todos ellos provenientes de VOX, a lo que ha de añadirse la retirada de su firma a tal iniciativa legislativa que 3 días después, el 23 de abril, el grupo de Unidas Podemos publicaría en el BOCG ${ }^{7}$.

No parece extraña aquella posición contraria. No hay que ser Nostradamus para saber que esta reforma pro animalista no será la última, sino un paso más para realizar en el futuro, más o menos próximo, otras. Lo advierte así la propia Proposición de Ley en su Exposición de Motivos: tras decir que los animales ya no son simples cosas (como luego veremos), sino seres sintientes (o seres vivos dotados de sensibilidad), cuyo bienestar la ley debe proteger (prohibiendo, por ello, su maltrato, abandono o muerte), reconoce, sin embargo, que, de momento, cabe seguirles aplicando, aunque supletoriamente, el régimen jurídico de los bienes y cosas (siempre con respeto a su sensibilidad y bienestar), aunque advirtiendo -en lo que ahora importa destacar- que "lo deseable «de lege ferenda» es que ese régimen protector vaya extendiéndose progresivamente a los distintos ámbitos en que intervienen los animales, y se vaya restringiendo con ello la aplicación supletoria del régimen jurídico de las cosas".

A su vista, pues, no parece osado anticipar otras prontas reformas que restrinjan, o incluso prohíban sin más, cualquier actividad para con los animales que se estime contraria a su sensibilidad y bienestar (piénsese, entre otros posibles ejemplos, en los zoos, en los circos, incluso en la caza y la pesca, de momento admitidas expresamente en la propia Proposición de Ley, o, cómo no, en el mundo de la tauromaquia, ...).

Con todo, y como suele decirse, la polémica está servida. Pero limitemos aquí y ahora la nuestra al contenido -estrictamente jurídico- de la Proposición de Ley ahora presentada en materia de animales, no para hacer un comentario completo ni siquiera crítico de la misma (lo que excedería, en mucho, de la finalidad y extensión de estas páginas), sino, admitido el espíritu de la reforma propuesta (según diremos en el siguiente epígrafe), para hacer una valoración más puntual de -solo- algunas de las nuevas normas que se proponen: algunas de ellas corregibles, o mejorables (como todo lo es en la vida), otras -puede que- sobrantes o innecesarias, y otras, sin embargo, ausentes, a pesar de su trascendencia práctica; y todo ello, naturalmente, a mi entender.

Vaya, pues, por delante y ante todo mi elogio a la propuesta presentada, aunque no exento de algunas críticas, todas ellas -espero- constructivas (hechas a modo de enmiendas).

\section{La Proposición de ley como obligada respuesta a nuestro Derecho comunitario, y autonómico.}

\section{Adecuación de la Proposición de ley española al Tratado de Funcionamiento de la Unión Europea, y a la necesaria protección del bienestar del animal -como ser vivo sensible- consagrada como nuevo principio general del Derecho.}

\footnotetext{
${ }^{4}$ La tramitación íntegra de tal Proposición de Ley puede consultarse en

http://www.congreso.es/portal/page/portal/Congreso/Congreso/Iniciativas?_piref73_2148295_73_1335437_1335437.next_page=/w c/servidorCGI\&CMD $=$ VERLST\&BASE $=I W 12 \& F M T=I N I T X D S S . f m t \& D O C S=1-$

$1 \&$ DOCORDER $=$ FIFO\&OPDEF $=$ ADJ\&QUERY $=\% 28122 \% 2 F 000134 *$ NDOC. $\% 29$

${ }^{5}$ Por todos, que son muchos, GIMÉNEZ-CANDELA, M., Animales en el Código Civil español: una reforma interrumpida, en dA.Derecho Animal (Forum of Animal Law Studies) 10/2 (2019) 7-12 (tomado texto completo de Dialnet), p. 18.

${ }^{6} \mathrm{De}$ "copia inteligente" la tilda la parlamentaria del PP, la $\mathrm{Sr}^{\mathrm{a}}$ Moro Almaraz (según puede verse en https://www.congreso.es/public_oficiales/L14/CONG/DS/PL/DSCD-14-PL-96.PDF\#page=26).

${ }^{7}$ Lo que, dicho sea de paso, justifica que el título del presente trabajo vaya, finalmente, entre interrogantes.
} 
Advertido el objetivo del presente trabajo, tal vez extrañe esta primera cuestión, dirigida a justificar la médula de la razón entera de la propuesta legal (lo que se conoce como su ratio legis). Pero leídas algunas de las intervenciones de ciertos parlamentarios de VOX que mostraron su voto contrario a la admisión a trámite de tal propuesta ${ }^{8}$, y que a buen seguro se repetirán a lo largo de su tramitación, no cabe otra opción que comenzar por justificar el espíritu y finalidad de la reforma propuesta, que en su consideración de los animales como seres sintientes cuyo bienestar ha de protegerse, lejos de ser una simple opción de política legislativa, es la alternativa única y obligada conforme al propio Derecho de la Unión Europea.

Así lo advierte la propia Exposición de Motivos de la Proposición de Ley, cuando dice (y tal vez lo que dice debiera ser la primera frase de su Exposición) que "el artículo 13 del Tratado de Funcionamiento de la Unión Europea exige que los Estados respeten las exigencias en materia de bienestar de los animales como «seres sensibles»"; a lo cual se ha llegado tras no pocos escollos":

En efecto, el bienestar de los animales y su protección por las personas fue ya con alcance general consagrado en el protocolo N. ${ }^{\circ} 33$, anejo al Tratado de Ámsterdam (de 1997), por el que se modificaban el Tratado de la Unión Europea, los Tratados constitutivos de las Comunidades Europeas y determinados actos conexos. Así lo fue, al inicio, para luego ser recogido, con algunas modificaciones, en el art. III-121 del Tratado por el que se establece una Constitución para Europa (de 2004), y, finalmente, consagrado en el propio cuerpo -articulado- del Tratado de Funcionamiento de la Unión Europea (de 2008), cuyo art. 13 califica, en efecto, a los animales como "sentient beings" o "seres sintientes" (como ya hacía antes el Protocolo $\mathrm{n}^{\circ}$ 33, aunque diciéndolo este en su Preámbulo). Dice hoy, íntegramente, dicho art. 13: "Al formular y aplicar las políticas de la Unión en materia de agricultura, pesca, transporte, mercado interior, investigación y desarrollo tecnológico y espacio, la Unión y los Estados miembros tendrán plenamente en cuenta las exigencias en materia de bienestar de los animales como seres sensibles ...", texto al que todos los países miembros de la Unión Europea deben adaptar su legislación (y que muchos -según veremos, como indica la propia Exposición de Motivos de la Proposición de Ley- ya han hecho).

Al inicio, sin embargo, tal necesaria protección del animal fue negada en su posible consideración como -nuevo- principio general del Derecho europeo. Así lo estimó la STJUE de 12 julio 2001 (caso "Jippes”), en el caso que enjuiciaba sobre la prohibición de vacunación y la necesidad de sacrificar abundante ganadería, sin posibilidad de ninguna vacunación, impuesta por algunas Directivas y Decisiones Europeas a fin de acabar eficaz y prontamente con la fiebre aftosa que, en aquel momento, se había expandido peligrosamente, como epidemia, por toda la Comunidad europea. En contra de tal medida se alegó, entre otras razones, que la misma vulneraba el principio de Derecho comunitario de bienestar del animal, al que, por entonces, hacía referencia -al menos la más directa- el Protocolo $n^{\circ} 33$, anejo al Tratado de Ámsterdam, aunque no estuviese recogido expresamente como uno de los objetivos del Tratado de la Unión Europea; omisión esta, sin embargo, que para El Tribunal de Justicia de la Unión Europea sería determinante para negar la existencia de tal -pretendidoprincipio general del Derecho comunitario, admitiendo -tan solo- una exigencia, como dice explícitamente el propio Protocolo $\mathrm{n}^{\mathrm{o}}$ 33: la de tener "plenamente en cuenta las exigencias en materia de bienestar de los animales como seres sensibles".

Pero desde aquella decisión, datada en 2001, según advierte cierta doctrina más reciente ${ }^{10}$, el panorama jurídico europeo ha cambiado cualitativamente, otorgando mayor peso a esa inicial exigencia, para erigirla, ya hoy, en un valor u objetivo constitucional europeo (en el art. III-121 del Tratado de Lisboa), en un estricto principio general del Derecho europeo, según demuestra su consagración en el propio articulado -art. 13- del mismísimo Tratado de Funcionamiento de la Unión Europea (de 2008), y no en su Preámbulo, como en cambio hacía el Protocolo $\mathrm{n}^{\circ} 33$, cuando, como es sabido, tales textos preambulares solo tienen un valor interpretativo, pero no vinculante, y carentes, en todo caso, de cualquier valor jurídico normativo ${ }^{11}$.

Así las cosas, aunque carentes de aplicación directa, por sí solas, desde aquellas normas europeas, por cuanto ya forman parte de nuestro propio ordenamiento, al haber sido ya publicadas en el BOE (cfr., arts. 96.1

\footnotetext{
${ }^{8}$ Me refiero a las intervenciones del parlamentario de VOX, el Sr. López Maraver, cuya transcripción aquí ahorro por cuestión de espacio (y que pueden verse en https://www.congreso.es/public_oficiales/L14/CONG/DS/PL/DSCD-14-PL-96.PDF\#page=26).

${ }^{9}$ Según detallo a continuación reproduciendo lo que ya dije en otro trabajo mío: "Clínicas veterinarias y paseos con animales de compañía ante el covid-19: una actividad esencial para el bienestar del animal como ser sintiente", en dA. Derecho Animal (Forum of Animal Law Studies) 11/2 (2020), páginas 17 a 29; en donde sintetizaba lo que, más in extenso, explicaba en mi libro "Crisis familiares y animales domésticos", dentro de la colección “Animales y Derecho", de la editorial REUS (Madrid 2019) páginas 19 a 30.

${ }^{10}$ BRELS, S., El bienestar de los animales: un nuevo principio general y constitucional de Derecho comunitario. Sentencia Jippes, TJCE, 2001, en dA.Derecho Animal (Forum of Animal Law Studies) 3/2 (2021) 7 páginas (tomado de Dialnet); más in extenso, y con cierta vehemencia, ALONSO GARCÍA, E., El bienestar de los animales como seres sensibles-sentientes: su valor como principio general, de rango constitucional, en el derecho español, en la ley digital, 2011 (tomado de Internet).

${ }^{11}$ Sobre el valor de los Preámbulos, Exposiciones de Motivos de las leyes, así como de los Considerandos de las normas europeas, permítaseme remitirme a mi monografia "Principio, realidad y norma: el valor de las exposiciones de motivos (y de los preámbulos)", de la editorial Reus (Méjico-Madrid 2015).
}

42 Derecho Animal. Forum of Animal Law Studies, vol. 12/2 
CE y 1.5 CC), nadie puede negar, ya hoy, y sin necesidad de culminar reformas legislativas, la existencia en nuestro propio Derecho de un nuevo principio general del Derecho, cual es el de proteger el bienestar animal, que, amén de su posible función inspiradora para nuestro legislador (como sucede ahora), e integradora, como fuente del Derecho supletoria de último grado (ex art. $1.4 \mathrm{CC}$ ), antes puede cumplir una función interpretativa de la norma vigente, pudiendo serlo por el propio aplicador en tanto el resultado de su interpretación sea respetuoso con la razón de la norma así interpretada (según exige el art. $3.1 \mathrm{CC}$ en su inciso final) ${ }^{12}$.

\section{Inspiración de la Proposición de Ley española en algunos Códigos europeos, aunque con olvido -que cabría subsanar- de nuestro Derecho autonómico.}

A tal fin de dar obligada satisfacción al principio europeo de protección del bienestar animal como ser dotado de sensibilidad, la Proposición de Ley española hace mención en su Exposición de Motivos de otros Ordenamientos en Europa que tal cosa ya han hecho, del modo en que sigue: "La reforma del régimen jurídico de los animales en el Código Civil español sigue las líneas que marcan otros ordenamientos jurídicos próximos, que han modificado sus Códigos Civiles para adaptarlos a la mayor sensibilidad social hacia los animales existente en nuestros días, y también para reconocer su cualidad de seres vivos dotados de sensibilidad: la reforma austriaca de 10 de marzo de 1986; la reforma alemana de 20 de agosto de 1990, seguida de la elevación de la protección de los animales a rango constitucional en 2002 al introducir en su Ley Fundamental el artículo 20 a); la regulación en Suiza, país que también incluye en su Constitución la protección de los animales y que modificó el Código Civil y el Código de las Obligaciones a este objeto; la reforma belga de 19 de mayo de 2009; y las dos más recientes: la reforma francesa de 16 de febrero de $2015^{13}$ $\mathrm{y}$, de manera muy especial por la proximidad con esta que ahora se presenta, la Ley portuguesa de 3 de marzo de $2017^{14}$, que estableció un estatuto jurídico de los animales y modificó, tanto su Código Civil, como el Código Procesal Civil y el Código Penal". Y añadiendo, tras otro apartado (referido al Tratado de Funcionamiento de la UE antes referido): "Aunque en las primeras reformas de los Códigos Civiles europeos (Austria, Alemania y Suiza) se utilizaba la formulación «negativa», en el sentido de que los animales no son cosas o no son bienes, se ha optado por las fórmulas más recientes de los Códigos Civiles francés y portugués, que prefieren una descripción «positiva» de la esencia de estos seres que los diferencia, por un lado, de las personas y, por otro, de las cosas y otras formas de vida, típicamente de las plantas"; una influencia gala y lusitana que no se limitará solo a tales extremos, sino a otras muchas normas (algunas de las cuales luego veremos), lo que, dicho sea de paso, será un dato interpretativo importante de nuestro Derecho (según previene el art. 3.1 CC cuando se refiere a "los antecedentes históricos y legislativos" de la norma a interpretar), en caso de que prospere la presente Proposición de Ley.

El contraste, sin embargo, no solo se muestra entre el Código Civil español y el de otros países, sino también dentro de nuestras propias fronteras. Al margen de la especial protección penal en favor de los animales domésticos introducida en 2003 y reforzada en 2015 para todo el país (cfr., sobre todo, los arts. 83 y 337 ss del Código Penal), y que la Proposición de Ley menciona al comienzo mismo de su Exposición, silencia, sin embargo, que son legión ya -prácticamente todas, incluidas las Ciudades de Ceuta y de Melillalas leyes autonómicas protectoras de los animales, sobre todo de los domésticos, o de compañía que también denominan (desde la Ley de 1990 de Castilla-La Mancha, hasta la más reciente, de 2019, de Navarra ${ }^{15}$ ), que consideran a los animales como seres vivos dotados de sensibilidad (física y psíquica, dicen algunas de tales

\footnotetext{
${ }^{12}$ ALONSO GARCía (pág. 9 y ss./50), defiende incluso la posibilidad de interpretar nuestra Constitución desde dicho principio, por aplicación de los arts. 93 y 10.2 CE.

${ }^{13}$ Para un primer estudio aproximativo, LeLANCHON, L. La reforma del estatuto jurídico civil de los animales en el Derecho francés, en dA.Derecho Animal (Forum of Animal Law Studies) 9/3 (2018) 72-79 (tomado texto completo de Dialnet).

${ }^{14}$ Para una visión panorámica, MoReIRA, A. La reforma del Código Civil portugués respecto al estatuto del animal, en dA.Derecho Animal (Forum of Animal Law Studies) 9/3 (2018) 80-91 (tomado de internet).

${ }^{15}$ Por puro orden cronológico de las normas vigentes, desde la más antigua a la más reciente, son: la Ley 7/1990, de 28 diciembre, de protección de los animales domésticos, de Castilla-La Mancha; la Ley 8/1991, de 30 abril, de protección de animales, de Canarias; la Ley 3/1998, de 18 marzo, de protección de animales, de Cantabria, la Ley 1/1992, de 8 abril, de protección de los animales que viven en el entorno humano, de las Islas Baleares; la Ley 6/1993, de 29 octubre, de protección de los animales, del País Vasco; la Ley 4/1994, de 8 julio, sobre protección de los animales de compañía, de Valencia; la Ley 5/1997, de 24 abril, de protección de los animales de compañía, de Castilla y León; la Ley 5/2002, de 23 mayo, de protección de los animales, de Extremadura; la Ley 13/2002, de 23 diciembre, de protección y derechos de los animales, de Asturias; la Ley 11/2003, de 19 marzo, de Protección animal, de Aragón; la Ley 11/2003, de 24 noviembre, de protección de los animales, de Andalucía; el Decreto Legislativo 2/2008, de 15 abril, por el que se aprueba el Texto refundido de la Ley de protección de los animales, en Cataluña; la Ley 4/2006, de 22 julio, de protección de los animales de compañía, de Madrid; la Ley 4/2007, de protección y bienestar de los animales de compañía, de Galicia; la Ley 6/2017, de 8 noviembre, de protección y defensa de los animales de compañía, de Murcia; la Ley 6/2018, de 26 noviembre, de protección de los animales, de La Rioja; y la Ley Foral 19/2019, de 4 abril, de protección de los animales de compañía, en Navarra. Mención separada merecen el Reglamento 2/15, de 23 marzo, de tenencia, protección y bienestar de animales de compañía de la Ciudad Autónoma de Ceuta, y el Reglamento de 26 enero 2017, Regulador de Sanidad Animal de la Ciudad Autónoma de Melilla.
} 
normas -como la catalana, la gallega o la murciana-), y les dotan, por ello, de un especial régimen tuitivo, inspirado en la necesidad de garantizar el bienestar del animal; lo que se hace, especialmente, es verdad, en el ámbito administrativo, aunque con alguna ocasional referencia al ámbito civil (como sucede en materia de responsabilidad por daños en aplicación del art. 1905 CC) ${ }^{16}$. Súmese a ello, además, que, en Cataluña, su propio Código civil, ya desde 2006 afirma en su art. 511-1 (al definir los bienes): "3. Los animales, que no se consideran cosas, están bajo la protección especial de las leyes. Solo se les aplican las reglas de los bienes en lo que permite su naturaleza".

Todo ello permite concluir afirmando en la actualidad la vigencia en España, cuando menos, de un nuevo principio general del Derecho: el de protección del bienestar de los animales, que si bien no ha encontrado aún, como principio inspirador, plasmación explícita en toda nuestra legislación nacional (sí en la penal, pero aún no en la civil), sí puede estimarse como principio ya vigente en aquella pléyade de normas autonómicas, que, por eso mismo, considero erróneamente obviadas, aunque fuese como argumento ad abundantiam, o por mera cortesía o elegancia, en la propuesta de reforma española, y que fácilmente cabría subsanar con una breve mención para ellas también en su Exposición de Motivos.

Pero advertida tal omisión, pasemos ya por fin a cuestiones de fondo de mayor calado.

\section{Entre personas y cosas: la consideración de los animales en la Proposición de Ley como bienes - aunque- singulares sometidos supletoriamente al régimen jurídico de bienes. $Y$ la consecuente propuesta de enmiendas.}

\section{La posición prudente de la Proposición, exenta de radicalismos extremos.}

Frente a las posiciones pro animalistas más radicales, que pretenden reconocer personalidad jurídica a los animales (con capacidad para tener derechos y deberes), y que según justifica el voto contrario de VOX es lo que hace la actual Proposición de Ley (llegándose a decir que con ella se va a "humanizar al animal y deshumanizar al hombre" ${ }^{17}$ ), lejos de ser esto último así, se mantiene aquella en una posición moderada, prudente, que ni siquiera estima a los animales como una suerte de tertium genus, entre personas y cosas, según proponen algunos de los animalistas más moderados ${ }^{18}$, sino como un bien singular, diverso de las demás cosas, pero sin personificarlos, siendo, podría decirse, su lema: humanidad con los animales, mas sin la necesidad de humanizarlos ${ }^{19}$.

Veámoslo con más detenimiento, proponiendo, a su propósito, algunas posibles mejoras y cambios en la Proposición de Ley presentada:

Frente a las primeras reformas de los Códigos Civiles europeos (Austria, Alemania y Suiza), que utilizaban la formulación "negativa", para decir que los animales no son cosas o no son bienes, las fórmulas más recientes de los Códigos Civiles francés y portugués, en mayor consonancia con el Derecho de la Unión Europea, han optado por una descripción "positiva" de la esencia de estos seres que los diferencia, por un lado, de las personas y, por otro, de las cosas y otras formas de vida, típicamente de las plantas: así, en el nuevo art. 515-14 del CC francés se dice que "Les animaux sont des êtres vivants doués de sensibilité"; por su parte, se dirá en el mismo art. 1 de la reforma portuguesa que "A presente lei estabelece um estatuto jurídico dos animais, reconhecendo a sua natureza de seres vivos dotados de sensibilidade", disponiendo ya, en el nuevo art. 201.B de su Código civil, que "Os animais são seres vivos dotados de sensibilidade e objeto de proteção jurídica em virtude da sua natureza".

Y ha sido esta normativa, en efecto, la que ha influido en la Proposición de Ley española, ya desde su misma Exposición de Motivos, donde destaca la idea (la ratio legis) de estimar a los animales como seres vivos dotados de sensibilidad cuyo bienestar ha de asegurar la ley -mas- en conjugación con su condición de posible objeto de propiedad, de posesión o de cualquier otro derecho (aunque diverso de las simples cosas), cuando dice: "La reforma afecta, en primer lugar, al Código Civil, con vistas a sentar el importante principio

\footnotetext{
${ }^{16}$ Así puede verse, por ejemplo, como pionera en tal definición, en el art. 1.2.a) de la Ley asturiana, así como en los arts. 1 y 2 de la ley catalana, 3.1 gallega, 1.3 murciana, 2.a) aragonesa, 1 y 2 de la Ley navarra, 6.1.a) madrileña y 6.2.a) riojana, que hablan -ambasde los animales como "seres sentientes", así como en el art. 1 de la ley andaluza, en cuya Exposición de Motivos se llega a decir que "los estudios realizados sobre las capacidades sensoriales y cognoscitivas de los animales no han dejado duda sobre la posibilidad de que éstos puedan experimentar sentimientos como placer, miedo, estrés, ansiedad, dolor o felicidad".

${ }^{17}$ Me refiero, de nuevo, a las intervenciones del parlamentario de VOX, el Sr. López Maraver (según puede verse en https://www.congreso.es/public oficiales/L14/CONG/DS/PL/DSCD-14-PL-96.PDF\#page=26)

18 Por todos, la monografía de De Torres Perea, J.M., El nuevo estatuto jurídico de los animales en el Derecho Civil: de su cosificación a su reconocimiento como seres sensibles, ed. REUS, Madrid, 2020 (que yo mismo recensioné en "Entre personas y cosas: los animales, ¿como tertium genus?", en Revista de Derecho Privado, 3 (mayo-junio 2020) páginas 113 a 128, del que tomo buena parte de cuanto sigue).

${ }^{19}$ Como ha recordado recientemente, Rogel VIDE, C., Personas, animales y androides, en RGLJ, 4 (2017) p. 684: "Los animales, sin ser considerados personas, han sido tenidos en cuenta permanentemente por el Derecho.".
} 
de que la naturaleza de los animales es distinta de la naturaleza de las cosas o bienes, principio que ha de presidir la interpretación de todo el ordenamiento. (...) De esta forma, ... se concreta que los animales son seres vivos -en lugar de lo que decía, más claramente sin embargo, la anterior Proposición de ley ya consensuada: «no son cosas, sino seres vivos»- dotados de sensibilidad, lo que no excluye -aclara- que en determinados aspectos se aplique supletoriamente el régimen jurídico de los bienes o cosas. (...) De este modo, los animales están sometidos solo parcialmente al régimen jurídico de los bienes o cosas, en la medida en que no existan normas destinadas especialmente a regular las relaciones jurídicas en las que puedan estar implicados animales, y siempre que dicho régimen jurídico de los bienes sea compatible con su naturaleza de ser vivo dotado de sensibilidad y con el conjunto de disposiciones destinadas a su protección"; añadiendo -y reconociendo- más adelante: "En nuestra sociedad los animales son, en general, apropiables y objeto de comercio. Sin perjuicio de ello, la relación de la persona y el animal (sea este de compañía, doméstico, silvestre o salvaje), ha de ser modulada por la cualidad de ser dotado de sensibilidad, de modo que los derechos y facultades que se posean sobre los animales han de ser ejercitados atendiendo al bienestar y la protección del animal, evitando el maltrato, el abandono y la provocación de una muerte cruel o innecesaria".

Y así lo expresa el ap. 1 del nuevo art. 333 del CC propuesto: "Los animales son seres vivos dotados de sensibilidad. Solo les será aplicable el régimen jurídico de los bienes en la medida en que sea compatible con su naturaleza y con las disposiciones destinadas a su protección.”. Es esta una norma, sin duda, inspirada en el nuevo art. 515.14 CC francés ("Les animaux sont des êtres vivants doués de sensibilité. Sous réserve des lois qui les protègent, les animaux sont soumis au régime des biens"); así como en el nuevo art. 201.B y D del portugués (que, tras decir en la letra B, que "os animais sâo seres vivos dotados de sensibilidade e objeto de proteçâo jurídica em virtude da sua natureza", afirma en su letra D: "Na ausencia de lei especial, sâo aplicáveis subsidiariamente aos animais as disposiçôes relativas às coisas, desde que nâo sejam incompatíveis com a sua natureza").

Y así lo demuestra hasta en el propio lenguaje, incluyendo a los animales entre los posibles objetos de derecho, de propiedad y posesión, mas como algo distinto del resto de bienes y de cosas (según se hace en tantísimas normas a reformar, consistiendo, precisa y sencillamente, tal reforma muchas veces en añadir la palabra "animal" junto a la de "bienes, cosas o derechos"); o como la simple expresión "animal salvaje o silvestre" sustituyendo a la de "animal fiero" del art. $465 \mathrm{CC}^{20}$ (donde, por cierto, cabe entender que hay una definición legal de animal de compañía doméstico -que viene del latín domus ${ }^{21}$ - fundada en el clásico animus revertendi ${ }^{22}$ ); o como que se hable en reiteradas ocasiones, desde la misma Exposición de Motivos, del "cuidado" del animal y no de su mera tenencia o disfrute (cfr., el nuevo art. 90.I.C ${ }^{23}$, donde, por cierto, se sustituye "cuidado" por "disfrute" que decía la propuesta consensuada ${ }^{24}$, o que frente a ella se prevea una suerte de régimen de visita con el animal tanto en caso de acuerdo entre los cónyuges como si es por decisión judicial en caso de desacuerdo -cfr., los nuevos arts. 94 bis $^{25}$ y $103.2^{\circ 26}$, cuando solo en este último hacía referencia a aquel régimen de visitas la anterior Proposición de Ley consensuada de 2019-); ...

Es verdad que la reforma ahora propuesta no habla de la dignidad, ni de los derechos del animal, ni de tantas otras cualidades que los pro animalistas más fervientes pretenden atribuirle, pero sí habla la Proposición de ley, conforme al Derecho europeo, de su bienestar, incluso en temas, tan íntimos, como en las consecuencias de las crisis familiares, donde se propone introducir una nueva letra c) en el art. 90 (sobre el

\footnotetext{
${ }^{20}$ Para un sintético y contundente comentario de dicho artículo, Rogel Vide, C., Los animales en el Código Civil (Madrid 2017) pp. $19-22$.

${ }^{21}$ Como nos recuerda Gil Membrado, C., Régimen jurídico civil de los animales de compañía (Madrid 2014) pág. 15.

${ }^{22}$ Según explico, con detenimiento, en mi obra "Crisis familiares y animales domésticos", dentro de la colección "Animales y Derecho", de la editorial REUS (Madrid 2019) páginas 151 y ss, frente a quienes (como PÉREZ MonGUió, J.M. El concepto de animal de compañía: Un necesario replanteamiento, en Revista Aragonesa de Administración Pública, núm. 51, Zaragoza, 2018, p. 278), durante la tramitación de la anterior Proposición de ley proponían una expresa definición de "animal de compañía" en el propio art. 333 CC (cuya acertada omisión valoro en aquel trabajo mío), lo que, dicho sea de paso, sirve también como crítica a las observaciones más recientes de VOX denunciando tal laguna en la nueva Proposición de Ley.

${ }^{23}$ Para decir: "El destino de los animales de compañía, en caso de que existan, teniendo en cuenta el interés de los miembros de la familia y el bienestar del animal, pudiendo preverse el reparto de los tiempos de convivencia y cuidado si fuere necesario, así como de las cargas asociadas al cuidado del animal".

${ }^{24}$ Ya por entonces, el PSOE (en su enmienda $n^{\circ} 82$ ), lo había propuesto, con la siguiente justificación: "Se trata de superar con esta reforma toda terminología que incida en la cosificación de los animales, como objetos de uso y disfrute por parte de los humanos. Resulta más adecuado a tal fin referirse a «guarda y cuidado» con el animal en lugar de a «disfrute» del mismo".

${ }^{25}$ Para decir: "La autoridad judicial confiará para su cuidado a los animales de compañía a uno o ambos cónyuges, y determinará, en su caso, la forma en la que el cónyuge al que no se le hayan confiado podrá tenerlos en su compañía, todo ello atendiendo al interés de los miembros de la familia y al bienestar del animal, con independencia de la titularidad dominical de este. Esta circunstancia se hará constar en el correspondiente registro de identificación de animales".

${ }^{26}$ Que permitirá al juez "Determinar, atendiendo al interés de los miembros de la familia y al bienestar del animal, si los animales de compañía se confían a uno o a ambos cónyuges, la forma en que el cónyuge al que no se hayan confiado podrá tenerlos en su compañía, así como también las medidas cautelares convenientes para conservar el derecho de cada uno.".
} 
posible contenido del convenio regulador), que diga: "El destino de los animales de compañía, en caso de que existan -copiando así el art. 1775.f) CC portugués ${ }^{27}$, pero añadiendo el nuestro lo que sigue:-, teniendo en cuenta el interés de los miembros de la familia y el bienestar del animal, pudiendo preverse el reparto de los tiempos de convivencia y cuidado si fuere necesario, así como las cargas asociadas al cuidado del animal". Después, introduciendo un nuevo art. 94 bis, para el caso en que los esposos no lleguen a un acuerdo: "La autoridad judicial confiará para su cuidado a los animales de compañía a uno o ambos cónyuges, y determinará, en su caso, la fórmula en la que el cónyuge al que no se le hayan confiado podrá tenerlos en su compañía, todo ello atendiendo al interés de los miembros de la familia y al bienestar del animal, con independencia de la titularidad dominical de este". La norma propuesta es casi una copia literal del nuevo art. 1793.A) del CC portugués ("Os animais de companhia são confiados a um ou a ambos os cônjuges, considerando, nomeadamente, os interesses de cada um dos cônjuges e dos filhos do casal e também o bemestar do animal"); pero con la importante diferencia de que durante la tramitación de la anterior propuesta española, la consensuada en 2019, se introdujo, como novedad, su inciso final ("con independencia de la titularidad dominical de este"), precisamente, con aquel fin, según justificaban -de forma idéntica- las enmiendas $\mathrm{n}^{\mathrm{o}} 7$ (del Grupo Mixto) y $\mathrm{n}^{\mathrm{o}} 83$ (del PSOE), que proponían añadir tal inciso último ${ }^{28}$. En consonancia con tal novedad, se proponía entonces, y así también en la nueva Proposición de Ley, modificar el art. 103 CC introduciendo una nueva medida que el juez puede adoptar: "Determinar, atendiendo al interés de los miembros de la familia y al bienestar del animal, si los animales de compañía se confían a uno o a ambos cónyuges, la forma en que el cónyuge al que no se hayan confiado podrá tenerlos en su compañía, así como también las medidas cautelares convenientes para conservar el derecho de cada uno".

A su vista, me pregunto cómo cabría imaginar una mayor protección al animal, o cómo descosificarlo, en tales normas sin ir más allá adentrándose en su personificación. La propuesta se ha mantenido en el límite, antes de dar ese salto -que considero- al vacío. Y para no darlo es inevitable mantener a los animales en el régimen de los bienes, aunque no como simples cosas, y sean estimados como -otro tipo de- bienes especiales merecedores de una protección -también- especial. De igual modo sucede con otro tipo de bienes, que el Derecho regula y protege singularmente (como son la propiedad intelectual, la industrial -que, no se olvide, son expresiones personalísimas del ingenio humano-, el patrimonio histórico,...), sin que por ello sea necesario crear para tales bienes una tercera categoría entre las personas y las cosas; como tampoco fue necesario crear otra categoría intermedia para las personas jurídicas (ni tal vez en un futuro para la inteligencia artificial y cualquier híbrido humanoide ${ }^{29}$ ), bastando con estimarlas como otra especie de personas (y eso que en las Fundaciones se personifica -todo- un patrimonio, aunque destinado por la voluntad de su fundador, lo que, sin embargo, no ha dado como resultado ningún tertium genus).

De aceptarse, en fin, como hace la reforma propuesta, que los animales sigan siendo objeto de derechos (de propiedad, de posesión, ...), desde un punto de vista -solo- dogmático, bastaría con abrir para los animales un espacio propio dentro de la categoría de bienes u objetos de derechos: junto a las cosas (como objeto inmediato de los derechos reales, y mediato de los de crédito), a la conducta de la persona (como objeto directo de los derechos de crédito), y a las cualidades de la persona (como objeto de los derechos de la personalidad). Y qué duda cabe de que en comparación con todas esas especies de objetos de derecho, a los animales solo cabe aplicar el régimen propio de las cosas, aunque con importantes singularidades (por la necesaria protección de su bienestar), que son, precisamente, las que justificarían su calificación como bien singular.

Y como prueba de todo ello, son los ejemplos que siguen contenidos en la propuesta de reforma española, en algunos de los cuales, sin embargo, me parece oportuno proponer alguna enmienda conforme al espíritu que guía a toda la Proposición de Ley:

\section{El novedoso reconocimiento del maltrato animal por su titular y, por ello, el posible olvido de su calificación -y refrendo- como abuso de derecho en el art. 7.2 CC.}

Palpable demostración de tal sensibilidad de la Proposición de Ley para con los animales, como bienes -aunque- singulares, se observa en la abolición del ius abutendi cuando se regula el concepto de animal, en

\footnotetext{
27 "Acordo sobre o destino dos animais de companhia, caso existam".

${ }^{28}$ Donde se decía: "A pesar de que a tenor de la redacción inicial de este nuevo precepto, el criterio por el que ha de regirse el juzgador en su decisión es el del interés de los miembros de la familia y el bienestar animal, debe atenderse a las problemáticas reales observadas en la práctica, en las que, por encima de los criterios anteriores, puede pretender un mejor derecho sobre un animal quien ostenta el microchip a su nombre. Por ello, en aras a la claridad y la seguridad jurídica en su aplicación, se propone incorporar la aclaración «con independencia de la titularidad dominical del animal»»."

${ }^{29}$ Sobre la posibilidad de que en un futuro -tal vez no muy lejano- se les pueda atribuir una personalidad fundacional, como ya viene sugiriendo el Parlamento Europeo en algunas de sus Resoluciones, permítaseme, de nuevo, remitirme a otro trabajo mío, donde recensiono una monografía sobre el tema, titulado "Entre personas y cosas: los robots", en Revista de Derecho Privado, 5 (septiembreoctubre 2020) págs. 123 a 138.
}

46 Derecho Animal. Forum of Animal Law Studies, vol. 12/2 
general, en el nuevo ap. 2 del art. 333 CC propuesto (aunque en la nueva propuesta se ha eliminado un inciso final muy revelador al respecto que sí aparecía en la anterior proposición consensuada de 2019, cuando añadía: "El derecho de disponer del animal no incluye el de abandonarlo o sacrificarlo salvo en los casos establecidos en las normas legales o reglamentarias"). Y, recuérdese, que así también se dice en su Exposición de Motivos, que "los derechos y facultades que se posean sobre los animales han de ser ejercitados atendiendo al bienestar y la protección del animal, evitando el maltrato, el abandono y la provocación de una muerte cruel e innecesaria"; límite, en la tenencia de cualquier animal cualquiera que sea el título que la legitime (de propiedad, usufructo, mera posesión,...), que, sin embargo, la Proposición de Ley omite en el concepto de propiedad del art. 348 CC (al que nada se añadía en la anterior propuesta de 2019 consensuada), al añadirse ahora tan solo que el dominio puede recaer sobre una cosa o "un animal".

No parece, sin embargo, oportuno ahondar en aquella prohibición del abuso del dominio de un animal en el propio art. $348 \mathrm{CC}$; al fin y al cabo, el animal también puede ser objeto de posesión (cfr., arts. 430 y ss de la propuesta de reforma), de usufructo (cfr., los arts. 355, 357 y 499 CC propuestos para su reforma en la Proposición de Ley), ...; mas tampoco en cada uno de ellos cabría recordar la prohibición de abuso de derecho, cuya referencia, tan repetida, sería cansina. En su lugar, bastaría con hacer una leve reforma en la norma clave que regula con alcance general el abuso de -cualquier- derecho: el art. 7.2 CC; a saber:

Refiriéndome yo mismo hace no mucho a la posible apertura de las clínicas veterinarias y a la posibilidad de pasear en compañía de animales durante el período de confinamiento más duro impuesto por el primer estado de alarma en nuestro país ${ }^{30}$, presentaba yo una advertencia, o una denuncia si se quiere -que paso a trascribir-, «ante los numerosos casos de agotamiento que, según algunas notas de prensa ${ }^{31}$, padecían muchos animales ante los paseos excesivos que en aquellos días de -supuesto- confinamiento aquellos realizaban. Cierto que como bienes especiales que son, los animales son objeto de derecho (de propiedad, de posesión, ...), y que como tales sus dueños, poseedores, ... tienen también su propio interés; así incluso se mantiene en la propuesta de reforma de CC -por entonces, me refería a la de 2019-. Pero ello no permite que tales dueños, poseedores, ... se extralimiten en el uso, en el ejercicio de su derecho. Pues junto a tal derecho, tienen también el deber de ejercitarlo, no solo conforme a su propio interés, sino también conforme al bienestar del animal. A fin de proteger tal bienestar y evitar aquellos paseos excesivos, no es necesario esperar a que aquella propuesta de reforma del CC se apruebe y entre en vigor -decía yo, refiriéndome a la Proposición de Ley de 2019-, para, entre otras cosas, reformar el actual art. 333 CC y así eliminar el clásico ius abutendi cuando del dominio de un animal se trate -prohibiendo expresamente el maltrato, el abandono, ...-. Hoy, como permiten los arts. 1.4 y $3.1 \mathrm{CC}$, cabe ya interpretar la norma vigente desde esa nueva realidad (de estimar a los animales como seres vivos dotados de sensibilidad) y conforme al principio de protección del bienestar animal, para exigir que la propiedad, la posesión, ... de un animal se ejercite de un modo apropiado: en interés propio del dueño y en el del propio animal. Y ya hoy hay mecanismos para evitar tal ejercicio del derecho propio en perjuicio del animal: como última medida -pues el Derecho penal siempre debe ser la última ratio, ahí está el delito de maltrato animal regulado -por lo que a este caso concierne- en el art. $337 \mathrm{CP}$ (sobre todo pensado para la protección de animales domésticos y domesticados); pero antes, sin la necesidad de que "la sangre llegue al río", en el ámbito civil existe la institución del abuso de derecho, que nuestro CC regula en su art. 7.2, cuando dice: "La Ley no ampara el abuso del derecho o el ejercicio antisocial del mismo. Todo acto u omisión que por la intención de su autor, por su objeto o por las circunstancias en que se realice sobrepase manifiestamente los límites normales del ejercicio de un derecho, con daño para tercero, dará lugar a la correspondiente indemnización y a la adopción de las medidas judiciales o administrativas que impidan la persistencia en el abuso". Cierto es que la norma habla de "daño para tercero", pensando, sin duda, en las personas, pero, del mismo modo en que nuestra interpretación -directa, pero extensiva- del art. 7.1 del RD 463/2020 -sobre el estado de alarma- se sustenta en la protección del bienestar animal, también cabe decir lo mismo de la aplicación del art. 7.2 CC cuando dicho bienestar del animal ha sido dañado por abuso de su dueño o poseedor. Ciertamente, la sanción no será la de indemnizar -directamente- al animal (al margen de los gastos sanitarios que requiera su sanación), pero sí la administrativa prevista en la legislación autonómica (en aquella legión de normas a que antes me referí), para el caso de maltrato animal. Todo sea, en fin, por el bienestar del propio animal como ser vivo dotado de sensibilidad», terminaba yo diciendo en aquella ocasión.

Como se ve, concluía yo en el art. 7.2 CC por vía -solo- interpretativa extensiva, ante el obstáculo contenido en su letra al hablar esta solo de "daño para tercero", pero que bien podría quedar aclarado por obra legislativa de la presente Proposición de Ley, haciendo que tal norma, en lugar de "daño para tercero", hable,

\footnotetext{
${ }^{30}$ Que aquí tomo, de nuevo, de mi trabajo "Clínicas veterinarias y paseos con animales de compañía ante el covid-19: una actividad esencial para el bienestar del animal como ser sintiente", en dA. Derecho Animal (Forum of Animal Law Studies) 11/2 (2020) páginas 17 a 29.

${ }^{31}$ Véase, por ejemplo, en https://wamiz.es/noticias/20861/los-perros-de-espana-estan-agotados-de-tanto-paseo-y-se-niegan-a-salir-ala-calle
} 
por ejemplo, de "daño para personas, bienes o animales".

3. La "falsa salida" de los animales como inmuebles por destinación en el nuevo art. 334 CC y la consiguiente exclusión de sus posibles embargo e hipoteca inmobiliaria (en los nuevos arts. 605.1 LEC y $111.1^{\circ} \mathrm{LH}$ ), aunque con -posible- olvido de la prenda sin desplazamiento posesorio (del art. 52.3 LHMYPSD).

Entre los elogios ya hechos hace un tiempo a la propuesta de reforma española de 2019, en que se inspira la actual también aquí, se congratulaban muchos de que, al ser derogado el n ${ }^{\circ} 6$ del art. $334 \mathrm{CC}$, ciertos animales (los adscritos a un fin económico -agrícola, ganadero o industrial- de una finca) hubiesen dejado de ser estimados como inmuebles por destinación. No en vano, de la letra del nuevo art. 333 bis contenido en la Proposición, parece que su intención es sacar a los animales de la clásica distinción entre bienes muebles e inmuebles, cuando dice: "Todas las cosas que son o pueden ser objeto de apropiación se consideran como bienes muebles o inmuebles. También -dice, como algo diverso, parece ser- pueden ser objeto de apropiación los animales, con las limitaciones que se establezcan en las normas legales y en la medida en que no lo prohíban".

El primer Código en hacer tal reforma fue el francés en cuyo nuevo art. 524, tras suprimir el elenco de animales que estimaba como inmuebles por destinación, dice, sin embargo, en su nuevo primer apartado que "Les animaux que le propriétaire d'un fonds y a placés aux mêmes fins sont soumis au régime des immeubles par destination." (y lo mismo hace en su nuevo art. 2501); de modo que lo que sacan por la puerta (la calificación de ciertos animales como inmuebles por destinación), lo vuelven a meter por la ventana (al someterlos al régimen propio de los inmuebles por destinación) ${ }^{32}$. Inevitablemente, porque no hay -o yo, al menos, no imagino- otra opción, lo mismo hace también la nueva propuesta española de reforma de nuestro CC: tras suprimir el actual $n^{\circ} 6^{\circ}$ del art. $334 \mathrm{CC}$, añade un nuevo ap. 2, donde se dice: "Quedan sometidos al régimen de los bienes inmuebles los viveros de animales, palomares, colmenas, estanques de peces o criaderos análogos, cuando el propietario los haya colocado o los conserve con el propósito de mantenerlos unidos a la finca y formando parte de ella de un modo permanente, sin perjuicio de la consideración de seres vivos dotados de sensibilidad de los animales y de las leyes especiales que los protegen".

De ahí la -inevitable- necesidad de excluirlos como posible objeto -extendido- de la hipoteca del inmueble al que pertenezcan, según se propone en un nuevo art. 111.1 LH: "Los animales colocados o destinados en una finca dedicada a la explotación ganadera, industrial o de recreo. No cabe el pacto de extensión de la hipoteca a los animales de compañía", respecto a los cuales hace lo propio el nuevo art. $605.1^{\circ}$ de la LEC propuesto al declararlos también inembargables, dejando solo como posible objeto de embargo sus frutos civiles ("rentas", dice), lo que también sucede tratándose de una hipoteca inmobiliaria (según dice hoy aquel art. $111 \mathrm{LH}$ en sus números $2^{\circ}$ y $3^{\circ}$, sobre frutos y rentas, que en la Proposición pasan a tener los números $3^{\circ}$ y $4^{\circ}$ ).

Pero, por esa misma razón, es posible que la Proposición de ley se haya olvidado de reformar el art. 52. $3^{\circ}$ de la Ley de Hipoteca mobiliaria y prenda sin desplazamiento de la posesión de 1954, cuando declara posible pignorar, aunque sin darle la posesión al acreedor, "los animales, así como sus crías y productos". El alcance de su posible reforma es, sin duda, una cuestión de política legislativa, en donde han de ponderarse importantes intereses económicos, pero, cuando menos, en mi opinión, del mismo modo en que aquel nuevo art. $111.1^{\circ} \mathrm{LH}$ que ahora se propone permite por pacto la extensión de la hipoteca a los animales destinados a cualquier fin económico (agrícola, ganadero o industrial), con exclusión en todo caso de los animales de compañía, así debiera hacerse, por pura coherencia interna de la propuesta de reforma, con el art. 52.3 LHMyPSDP.

En cierto modo, así lo propuso respecto a la anterior Proposición de Ley, la consensuada de 2019, el grupo parlamentario de Ciudadanos (en su enmienda $\mathrm{n}^{\circ} 40$ ), aunque refiriendo la necesidad de reforma al art. 1864 CC (sobre la prenda clásica, la que trasfiere la posesión de la cosa pignorada al acreedor), proponiendo añadir un nuevo segundo párrafo que dijese: "En ningún caso podrán ser objeto de prenda los animales de compañía", justificándolo, precisamente, por su sintonía con la reforma propuesta en materia de embargos y de hipoteca: "Con el mismo espíritu y sentido que la reforma de la Proposición respecto a la legislación hipotecaria, así como la proscripción de la embargabilidad del animal de compañía y, en fin, su caracterización como objeto extrapatrimonial, ha de limitarse de igual modo el ámbito de la prenda (que no resulta diferente, en cuanto a su configuración general de garantía real y patrimonial accesoria a un crédito a la hipoteca)".

\footnotetext{
${ }^{32}$ No parece, sin embargo, darse cuenta de ello GIMÉNEZ-CANDELA (pp. 13 y 14), celebrando tan solo la supresión, olvidando la asimilación de regímenes jurídicos. 
Personalmente, sin embargo, me muestro más proclive a tal inclusión en el art. 52.3 LHMyPSD, pues, conforme a la razón, precisamente, de su gestación, ¿quién va a dar en prenda, en posesión al acreedor o a un tercero, un animal que le sirve para su sustento o para su compañía?

\section{La posible "salida en falso" de los animales como bienes muebles en el nuevo art. $346 \mathrm{CC}$, y su indudable repercusión -sobre todo- en Derecho de familia (en los arts. 96, 1320, 1321 CC, entre otros, - tal vez- olvidados en la Proposición de ley).}

Otra posible enmienda, según creo, cabe hacer de la reforma que se hace -aparentemente solo de redacción- del párrafo $2^{\circ}$ del art. $346 \mathrm{CC}$, que pasaría a decir: "Cuando se use tan solo la palabra muebles no se entenderán comprendidos el dinero, los créditos, efectos de comercio, valores, alhajas, colecciones científicas o artísticas, libros, medallas, armas, ropas de vestir, arreos de caballerías o carruajes, granos, caldos y mercancías, ni otras cosas que no tengan por principal destino amueblar o alhajar las habitaciones, salvo el caso en que del contexto de la ley o de la disposición individual resulte claramente lo contrario".

En tan detallado elenco se ha limitado la Proposición a sustituir la referencia a "caballerías o carruajes y sus arreos" que hace hoy tal norma por la de "arreos de caballerías o carruajes" que ahora se propone; mas, ¿con qué intención: para dejar excluidos de los muebles a los animales en general, o tan solo sus utensilios de uso o manejo? Si atendemos a los antecedentes históricos de la norma (especialmente a las explicaciones que daba García Goyena de su correlativo contenido en el Proyecto de CC de 1851 que, prácticamente tal cual, pasó a aquel art. $346 \mathrm{CC}$ ), la razón de tal norma era solo estimar como muebles, incluidos en tan genérica expresión, los de menaje o ajuar domésticos, quedando, pues, excluidos los demás bienes muebles ${ }^{33}$, entre los que hoy habría que seguir incluyendo -para tal exclusión- a los animales que no estén destinados a un fin económico (según lo visto antes al comentar la reforma propuesta del art. $334 \mathrm{CC}$ ). Bien es cierto (como decíamos también en el epígrafe anterior), que el nuevo art. 333 bis parece sacar a los animales de la clásica bipartición entre bienes muebles e inmuebles; sin embargo, aún permanece una norma, no reformada en la Proposición de Ley, como es el art. 335 CC, en cuya definición de bienes muebles, tras excluir los que sean inmuebles (por remisión al Capítulo anterior, donde no se comprende aquel nuevo art. 333 bis), ofrece un concepto, por inclusión, en su inciso final de lo que sí son bienes muebles, en donde, sin duda, encajarían los animales, cuando dice que son tales "en general todos los que se pueden transportar de un punto a otro".

¿Son o no son, pues, bienes muebles los animales? No es una cuestión retórica, ni prurito escolástico, sino de gran trascendencia práctica; pensemos en lo que afecta al Derecho de familia, sin duda, la materia estrella en la reforma, por ser hoy tan litigiosa según reconoce la propia Proposición de Ley en su Exposición de Motivos, cuando dice: "Asimismo, se introducen en las normas relativas a las crisis matrimoniales preceptos destinados a concretar el régimen de custodia de los animales de compañía, cuestión que ya ha sido objeto de controversia en nuestros tribunales. Para ello, se contempla el pacto sobre los animales domésticos, y se sientan los criterios sobre los que los tribunales deben tomar la decisión de a quién entregar el cuidado del animal, atendiendo a su bienestar". Mas, ¿no se ha tenido en cuenta, por ejemplo, en que lo mejor para el bienestar del animal, como para el de los hijos menores, con discapacidad, ... es quedarse en la vivienda familiar conforme prevé el art. 96 CC? ¿Acaso cabría entender a la mascota incluida entre los "objetos de uso ordinario" a que se refiere dicho art. 96 CC? O, volviendo a los inmuebles por destinación, ¿tal vez habría que estimar al animal doméstico como parte de la propia vivienda familiar a la que se ha de estimar destinada afectivamente? Por supuesto, no es este lugar en que tratar todo esto (ya lo hice en una obra anterior mía, a la que me remito ${ }^{34}$, donde desde una interpretación -histórica, lógica y sociológica- de los arts. $334.6^{\circ}$ y $465 \mathrm{CC}$, perfectamente trasladable a los arts. 334.II y 465 que ahora se proponen, cabía incluir entre los inmuebles por destinación del art. $334.6^{\circ} \mathrm{CC}$-o en el nuevo 334.II- a los animales domésticos, mediante una suerte de destinación afectiva o emocional con fundamento en el animus revertendi, en la querencia, a que se refiere el art. $465 \mathrm{CC}$, para así concluir, con un criterio seguro, que el animal doméstico sea parte de la vivienda en la aplicación del art. 96 CC para cuando en caso de crisis familiar la pareja rota no llegue a un acuerdo sobre

\footnotetext{
${ }^{33}$ Para mayores detalles sobre la razón histórica del art. 346, me remito, de nuevo, a mi monografía "Crisis familiares y animales domésticos", dentro de la colección "Animales y Derecho", de la editorial REUS (Madrid 2019) págs. 117 a 125. Baste aquí con recordar cuando decía GARCÍA GOYENA que la "espresion de muebles sola tal vez -decía- se esplicaria mejor según el uso común con el nombre de ajuar, en latín supellex", y aclaraba luego que "la palabra muebles tiene, como todas, un significado generalmente recibido, y puede decirse que comprende todo lo que sirve para el adorno y uso ordinario de la casa. "Amueblar es, según el Diccionario, alhajar ó adornar con muebles una casa»", lo que, finalmente, tendrá expresión en el art. 382.II in fine del Proyecto de CC-1851 ("cosas mas que las que sirven para amueblar ó alhajar la casa"), y se mantendrá en el actual art. 346 CC ("otras cosas que no tengan por principal destino amueblar o alhajar las habitaciones"), demostrando ello, como advertimos, la ecuación entre muebles y ajuar

${ }^{34}$ En efecto, me remito, de nuevo, a mi librito "Crisis familiares y animales domésticos", dentro de la colección "Animales y Derecho", de la editorial REUS (Madrid 2019).
} 
qué hacer con la mascota); pero tal vez convenga que el legislador lo piense, aclarando él mismo y no dejando aquellas opciones a la interpretación en manos del aplicador del Derecho (sobre todo, en las del juez), a quien, amén de proporcionarle una solución justa, sería esta además segura, al no tener el juez que elucubrar en cada caso qué es lo mejor para el bienestar del animal.

Y no solo importa la calificación de los animales como bienes muebles en caso de crisis familiar (único tema al que se refiere la Proposición de Ley, con cierta lógica, al ser el más conflictivo), sino también durante la normal convivencia familiar, o en su disolución por causas naturales (como la muerte): piénsese, por ejemplo, en el art. 1320 CC sobre disposición de la "vivienda habitual y los muebles de uso ordinario de la vivienda", que aun siendo de titularidad exclusiva de uno de los cónyuges, ambos han de consentir (como sucede, por cierto, también en el vigente art. 96.IV CC aun habiendo ruptura matrimonial): ¿qué sucederá, entonces, si el animal de compañía es propiedad de uno de los esposos y este quiere venderlo o regalarlo: bastará con su sola voluntad o habrá de consentir el otro cónyuge por estimar que la mascota es parte del hogar -sea de la vivienda (como yo defiendo) o de su mobiliario-?; o piénsese en el derecho de predetracción del art. $1321 \mathrm{CC}$, que en este punto guarda cierta sintonía con el art. $346 \mathrm{CC}$ antes referido, en cuya virtud fallecido uno de los esposos, quien quede viudo podrá quedarse con el ajuar doméstico sin computarlo en la herencia: ¿cabrá, entonces, incluir el animal de compañía dentro de la predetracción o habrá que incluirlo en el común haber hereditario? Sin la necesidad de que yo exponga mi opinión, quede advertido el legislador que de no reformarse también tal norma, a la mascota no le resultaría en principio aplicable tal art. 1321.

Tras pensarlo, pues, habrá el legislador de optar por no reformar ninguna de tales normas, dejando, en su caso, el problema en manos del intérprete, o bien por aclarar expresamente si incluir o no a los animales de compañía en las normas indicadas (los arts. 96, 1320 y 1321 CC, sobre todo). Por mi parte, creo que, prima facie, el propio bienestar del animal recomienda tal inclusión; pero quede en manos del legislador tomar la decisión final, que en las mías quedará su correcta interpretación para incluir a los animales de compañía en la previsión de aquellas normas (menos difícil para el art. $96 \mathrm{CC}$, más difícil en el caso del art. 1320, y prácticamente imposible en el del art. $1321 \mathrm{CC}$ ).

Y no son tales las únicas normas sobre Derecho de Familia -posiblemente- olvidadas en la Proposición de Ley. Otras hay, aunque -por fortuna- ya no referidas a la consideración mobiliaria o inmobiliaria de los animales. Veámoslas para así, por fin, finalizar.

\section{La aclaración -posiblemente- innecesaria -y hasta perturbadora- del nuevo art. $1346.1^{\circ} \mathrm{CC}$ y el olvido en aclarar si la tenencia y el cuidado del animal son carga del matrimonio y forman parte de la potestad y del trabajo domésticos (los olvidados arts. 1319, 1362 y 1438 CC).}

En la nueva Proposición de Ley se pretende modificar el numeral $1^{\circ}$ del art. $1346 \mathrm{CC}$, destinado a enumerar qué bienes son privativos en un matrimonio sometido al régimen de gananciales, para entender como tales privativos: "Los bienes, animales y derechos que le pertenecieran al comenzar la sociedad" (aparentemente, pareciendo hacer tal precisión en coherencia con tantas otras normas, antes por mí advertidas, donde la Proposición se limita a añadir la palabra "animal" junto a la de "bienes, cosas o derechos").

No es original tal -supuesta- aclaración. Ya en la Proposición consensuada de 2019 se pretendía incluir un nuevo $\mathrm{n}^{\mathrm{o}} 9$ en el art. $1346 \mathrm{CC}$ (que también contiene el CC portugués en su art. 1733.h ${ }^{35}$ ), para mencionar como bienes privativos "Los animales de compañía que perteneciesen a cada cónyuge antes de casarse", introducido a propuesta de grupos parlamentarios tan dispares como Ciudadanos, Unidas Podemos y PP (en las enmiendas $\mathrm{n}^{\circ} 38,70$ y 113 , respectivamente): así lo propusieron Ciudadanos y PP como simple "mejora técnica", pero según UNIDAS PODEMOS para así "evitar posibles conflictos que puedan surgir en el reparto de la tenencia de un animal de compañía entre los miembros de la pareja ante el sobrevenimiento de las crisis familiares"; una explicación que, sin duda, se contradice con el art. 94 bis, cuya prevalencia -entiendo- se justifica por su propia finalidad: el bienestar del animal.

En efecto, claro y contundente se muestra dicho art. 94 bis, que se pretende añadir para el caso en que los esposos no lleguen a un acuerdo al respecto, cuando dice: "La autoridad judicial confiará para su cuidado a los animales de compañía a uno o ambos cónyuges, atendiendo al interés de los miembros de la familia y al bienestar del animal, con independencia de la titularidad dominical de este". La norma propuesta es casi una copia literal del nuevo art. 1793.A) del CC portugués ("Os animais de companhia são confiados a um ou a ambos os cônjuges, considerando, nomeadamente, os interesses de cada um dos cônjuges e dos filhos do casal e também o bem-estar do animal.”); pero con la importante diferencia de que durante la tramitación de la propuesta española se introdujo, como novedad, su inciso final ("con independencia de la titularidad dominical de este"), precisamente, con aquel fin, según justificaban -de forma idéntica- las enmiendas $\mathrm{n}^{\circ} 7$ (del Grupo

35 "Os animais de companhia que cada um dos cônjuges tiver ao tempo da celebração do casamento".

50 Derecho Animal. Forum of Animal Law Studies, vol. 12/2 
Mixto) y no 83 (del PSOE), que proponían añadir tal inciso último: "A pesar de que a tenor de la redacción inicial de este nuevo precepto, el criterio por el que ha de regirse el juzgador en su decisión es el del interés de los miembros de la familia y el bienestar animal, debe atenderse a las problemáticas reales observadas en la práctica, en las que, por encima de los criterios anteriores, puede pretender un mejor derecho sobre un animal quien ostenta el microchip a su nombre. Por ello, en aras a la claridad y la seguridad jurídica en su aplicación, se propone incorporar la aclaración «con independencia de la titularidad dominical del animal».". Tal vez por ello, atendida la intención originaria del legislador (me refiero a la justificación de UNIDAS PODEMOS), resulte criticable y, por ello, innecesaria, por perturbadora incluso, la propuesta de un nuevo $\mathrm{n}^{\circ}$ 1 en el art. 1346 CC (que, no obstante, de mantenerse habría que resolver negando la razón aportada para su inclusión desde Unidas Podemos ante la razón, expuesta durante su tramitación, que justifica el último inciso del art. 94 bis in fine, más acorde este con la razón o espíritu general de la reforma).

En cambio, sí parece necesario aclarar expresamente en la Proposición de Ley otras cuestiones, que también afectan al desarrollo normal de la vida familiar, o matrimonial, y que, sin embargo, dicha Proposición sencillamente silencia: que la tenencia y el cuidado del animal doméstico (su alimentación e higiene, paseos, peluquería, gastos veterinarios, ...) formen parte de la tradicionalmente llamada potestad doméstica o de las llaves a que se refiere el art. $1319 \mathrm{CC}$, si se computa o no como trabajo doméstico, según previene el art. 1438 $\mathrm{CC}, \mathrm{y}$, sobre todo, si son o no una carga matrimonial, a que se refiere el art. $1362 \mathrm{CC}$, cuando enumera los gastos que han de sufragarse con el patrimonio ganancial. De quererse que así sea, lo que resulta lógico y coherente con el bienestar del animal, bastaría también con hacer en tales normas un leve añadido: por ejemplo, que el art. $1319 \mathrm{CC}$ hablara de "las necesidades ordinarias de la familia, encomendadas a su cuidado, así como el de los animales de compañía, cualquiera que sea su dueño, ..."; en cuanto al art. 1362 CC, tal vez cabría entender incluidos tales tenencia y cuidado del animal doméstico como gastos a cubrir con la sociedad de gananciales, ya sea el animal de ambos cónyuges o de uno solo de ellos (según refiere aquella norma, respectivamente, en sus números $2^{\circ}$ y $3^{\circ}$ cuando estos hablan de la "tenencia y disfrute" de los bienes gananciales y de la "administración ordinaria" de los bienes privativos); pero no se olvide: por un lado, que el nuevo art. $1346.1^{\circ}$ (cuya oportunidad antes he cuestionado), parece querer distinguir los animales de los demás "bienes" privativos (denominación que conserva el art. $1362 \mathrm{CC}$, sin mayor precisión sobre los animales), y, por otro, que el propio concepto de carga matrimonial, tan indeterminado, es hartamente debatido en doctrina ${ }^{36}$, hasta el punto de que una concepción estrecha o excesivamente técnica pudiera entender excluida de entre las cargas familiares a compartir la tenencia y cuidado de los animales; todo lo cual hace aconsejable, ahora sí, la inclusión expresa de dicho cuidado y mantenimiento de las mascotas, del mismo modo en que así lo prevé el inciso final del nuevo art. 90.I.C) propuesto en la reforma que, referido al convenio regulador de separación y divorcio que recoge el "reparto de los tiempos de convivencia y cuidado si fuere necesario, -añade- así como de las cargas asociadas al cuidado del animal" (añadido que lo fue en la tramitación de la anterior Proposición de Ley, consensuada en 2019, por iniciativa de UNIDAS PODEMOS ${ }^{37}$ y de PSOE $^{38}$ ). Se trata, pues, de una reforma -la del art. 1362 CC- exigida por pura coherencia interna de toda la reforma, para que así quede claro, en definitiva, que el cuidado del animal es una carga de la familia, no solo tras la ruptura o crisis familiar, sino -precisamente por serlo así ya antes de cualquier posible crisisdurante la convivencia normal de la familia.

A tal respecto, me atrevería, incluso, a sugerir en la posible reforma del art. $1362 \mathrm{CC}$ que se procure un cierto paralelismo entre tal cuidado de los animales de compañía y el de los hijos, que también es carga de la sociedad de gananciales referida en el $\mathrm{n}^{\mathrm{o}} 1^{\circ}$ de aquel art. $1362 \mathrm{CC}$, donde incluso queda aclarado que el hijo no común ha de ser así mantenido -por ambos cónyuges- cuando aquel conviva en el mismo hogar familiar, lo que, una vez más, concuerda también con nuestra propuesta hecha -en el epígrafe anterior- sobre la necesidad de aclarar también en el art. 96 CC la consideración del animal doméstico como parte del hogar familiar.

Además, de este modo, una vez incluido expresamente el cuidado del animal entre las cargas del matrimonio, ya iría así también de suyo incluido su cuidado como contribución en el trabajo doméstico a que se refiere el art. $1438 \mathrm{CC}$.

\footnotetext{
${ }^{36}$ Recuérdese, entre otros, el ferviente debate habido hace unos años acerca de si el pago del préstamo hipotecario por la adquisición de la vivienda familiar era o no una carga del matrimonio (debate que, entre otros, puede verse en el trabajo de GARCíA MAYO, M., Pago de los gastos vinculados a la vivienda familiar atribuida tras la crisis matrimonial, en La Ley Derecho de Familia: revista jurídica sobre familia y menores, 24 (2019) págs. 37 a 51). Acerca de la dificultad de tal concepto en general, optando, además, por un concepto estricto, véase, por todos, Moreno Mozo, F., Cargas del matrimonio y alimentos (Granada 2008).

${ }^{37}$ En su enmienda $n^{\circ} 50$, que justificaba diciendo: "Se deben contemplar las cargas asociadas al cuidado del animal, como por ejemplo, los gastos veterinarios, alimentación, higiene, etc".

${ }^{38}$ En su enmienda ${ }^{\circ} 82$, con similar justificación: “, debe contemplar también el pacto previsto los acuerdos relativos a las cargas asociadas al cuidado conjunto del animal, como por ejemplo, los gastos veterinarios”.
} 


\section{Y a modo de epílogo: ¿otros posibles olvidos que enmendar en la nueva Proposición de Ley sobre animales?}

Hasta aquí han quedado expuestas las mejoras que, a vuelapluma a fin de llegar a tiempo durante su tramitación, entiendo más sobresalientes. Pero he de confesar que, por espacio y tiempo, no he abordado todo el contenido de la reforma propuesta (en temas como la ocupación, reformada en sus arts. 610 a $612 \mathrm{CC}$, la compraventa, en los arts. 1484, 1485, 1492 y 1493, ni en cuestiones tan novedosas como la responsabilidad por daños causados al animal, prevista en el nuevo art. $333.4 \mathrm{CC}$-no ya a los causados por el animal, hace tiempo contemplado en el art. $1905 \mathrm{CC}^{39}$-).

Ni siquiera he abordado otras cuestiones -aun solo- de Derecho Civil, que ni siquiera la Proposición parece atender (como la posibilidad de regular la adopción de animales en el $\mathrm{CC}^{40}$, la posibilidad de que la tenencia de animales de compañía pueda ser prohibida en los contratos de alquiler o en los estatutos de una comunidades de vecinos ${ }^{41}$, o que incluso el animal doméstico pudiera recibir parte de la herencia de su dueño a través de una suerte de fideicomiso de residuo ${ }^{42}, \ldots$ ); cuestiones todas ellas, y otras posibles, que, sin embargo, hic et nunc no puedo ya abordar, y cuyo tratamiento corresponde abordar a otros más entendidos que yo en ellas.

Pero tiempo habrá para todo ello, pues, como reconoce y advierte la propia Proposición de Ley en su Exposición de Motivos, esta nueva reforma no es más que un paso más, siendo "lo deseable «de lege ferenda» ... que ese régimen protector vaya extendiéndose progresivamente a los distintos ámbitos en que intervienen los animales, y se vaya restringiendo con ello la aplicación supletoria del régimen jurídico de las cosas". Y que así sea, por el propio bienestar del animal como ser vivo dotado de sensibilidad.

\section{Bibliografía}

- ALÁEZ CORRAL, B., Algunas claves de la futura reforma del Estatuto Jurídico civil del animal en España, en dA.Derecho Animal (Forum of Animal Law Studies) 9/3 (2018) 48-55 (tomado texto completo de Dialnet).

- ALONSO GARCÍA, E., El bienestar de los animales como seres sensibles-sentientes: su valor como principio general, de rango constitucional, en el derecho español, en la ley digital 2011 (tomado de Internet).

- ARRIBAS ATIENZA, P., El nuevo tratamiento civil de los animales, en Diario La Ley, nº 9136, Sección Tribuna, 9 de Febrero de 2018 (tomado de internet).

- BRELS, S., El bienestar de los animales: un nuevo principio general y constitucional de Derecho comunitario. Sentencia Jippes, TJCE, 2001, en dA.Derecho Animal (Forum of Animal Law Studies) 3/2 (2012) 7 páginas (tomado de Dialnet).

- DE TORRES PEREA, JM., El nuevo estatuto jurídico de los animales en el Derecho civil: de su cosificación a su reconocimiento como seres sensibles (Madrid 2020).

- GIL MEMBRADO, C., Régimen jurídico civil de los animales de compañía (Madrid 2014).

- GIMÉNEZ-CANDELA, M., Descosificación de los animales en el Cc. español, en dA.Derecho Animal (Forum of Animal Law Studies) 9/3 (2018) pp. 7-27 (tomado texto completo de Dialnet).

- GIMÉNEZ-CANDELA, M., Animales en el Código Civil español: una reforma interrumpida, en dA.Derecho Animal (Forum of Animal Law Studies) 10/2 (2019) pp. 7-12 (tomado texto completo de Dialnet).

- GONZÁLEZ LACABEX, M., La adopción de animales de compañía en el Derecho español, en D. Favre y T. Giménez-Candela (editores), Animales y Derecho. Animals and the Law (Valencia, 2015) pp.251-259.

- LELANCHON, L., La reforma del estatuto jurídico civil de los animales en el Derecho francés, en dA. Derecho Animal (Forum of Animal Law Studies) 9/3 (2018) pp. $72-79$ (tomado texto completo de Dialnet).

- MOREIRA, AR., La reforma del Código Civil portugués respecto al estatuto del animal, en

\footnotetext{
${ }^{39}$ Sobre el art. 1905 CC, por todos, Rogel VIDE, C., Los animales en el Código Civil (Madrid 2017) pp. 81 ss.

40 Por todos, GonzÁlez Lacabex, M. La adopción de animales de compañía en el Derecho español”, en D. Favre y T. GiménezCandela (editores), Animales y Derecho. Animals and the Law (Valencia 2015) pp. 251-259.

${ }^{41}$ Por todos, VIVAS TESÓN, I., Las inmisiones por tenencia de animales de compañía en inmuebles en régimen de propiedad horizontal (Madrid 2019).

${ }^{42}$ Como propone De Torres Perea, JM., El nuevo estatuto jurídico de los animales en el Derecho Civil: de su cosificación a su reconocimiento como seres sensibles (Madrid, 2020) págs. 168 y 169.
} 
dA.Derecho Animal (Forum of Animal Law Studies) 9/3 (2018) pp. 80-91 (tomado de internet).

- PÉREZ MONGUIÓ, JM., El bienestar animal como una nueva concepción de la protección, en Animalia: revista profesional de los animales de compañía, 189 (2006) pp.56-60.

- PÉREZ MONGUIÓ, JM., El concepto de animal de compañía: Un necesario replanteamiento, Revista Aragonesa de Administración Pública, 51 (Zaragoza 2018) pp. 244-280.

- ROGEL VIDE, C., Los animales en el Código Civil (Madrid 2017).

- ROGEL VIDE, C., Personas, animales y Derechos (Madrid-México 2018).

- ROGEL VIDE, C., Personas, animales y androides", en RGLJ, 4 (2017) pp. 681-693.

- VIVAS TESÓN, I., Las inmisiones por tenencia de animales de compañía en inmuebles en régimen de propiedad horizontal (Madrid 2019). 